Pacific Journal of Mathematics

THE FIXED POINT PROPERTY FOR ARCWISE CONNECTED 


\title{
THE FIXED POINT PROPERTY FOR ARCWISE CONNECTED SPACES: A CORRECTION
}

\author{
R. E. SMithson AND L. E. WARD, JR.
}

\begin{abstract}
Several years ago the second author stated a fixed point theorem for a class of arcwise connected spaces which includes the dendroids as well as certain nonunicoherent continua. Subsequently the first author detected a flaw in the proof. The present collaboration has produced a correct proof. Since the theorem has not been subsumed in the literature of the intervening years and since other authors have alluded to it, it seems desirable to publish the new proof.
\end{abstract}

For recent references to the theorem, see [1], [4] and [7]. The original, erroneous argument can be found in [5]. (The error (p. 1277) occurs in the assertion that $S^{\prime}=\bigcup\left(S_{r}^{\prime}\right\}$ is connected, and hence that $\mathscr{N}$ has a maximal member.)

In the present exposition a few changes have been made in terminology. In what follows an are is a compact connected Hausdorff space with exactly two non-cutpoints. A space $X$ is arcwise connected if for each two elements $x$ and $y$ of $X$ with $x \neq y$, there exists an arc $[x, y]$ contained in $X$. It is convenient to write $[x, x]=$ $\{x\}$ and $[x, y)=(y, x]=[x, y]-\{y\}$. A circle is the union of two arcs which meet only in their endpoints. We write $\square$ to denote the empty set. If $e \in X$ then an $e-r a y$ is the union of a maximal nest of $\operatorname{arcs}[e, x]$. If $R$ is an $e$-ray then

$$
K_{R}=\bigcap\{\overline{R-[e, x)}:[e, x] \subset R\},
$$

where the bar denotes closure. If $X$ is not compact then it may be that $K_{R}$ is empty, but in the compact case this cannot occur.

THEOREM. If $X$ is an arcwise connected Hausdorff space which contains no circle, if $e \in X$ and if $f: X \rightarrow X$ is continuous, then $f$ has a fixed point or there exists an e-ray $R$ such that $f\left(K_{R}\right) \subset K_{R}$.

CoRollary. If $X$ is an arcwise connected Hausdorff space which contains no circle and if there exists $e \in X$ such that $K_{R}$ has the fixed point property for each e-ray $R$, then $X$ has the fixed point property.

Before embarking on the proof of the theorem, some subsidiary results will be helpful.

Lemma 1. If $X$ is a Hausdorff space, $A$ is an arc and $f: A \rightarrow$ 
$X$ is continuous, then $f(A)$ is arcwise connected.

Since $A$ is locally connected and compact it follows that $f(A)$ is locally connected. In contrast to the case where $A$ is separable, the arcwise connectivity of $f(A)$ is not immediate [3]. A proof of Lemma 1 can be found in the thesis of J. K. Harris [2]; it is a modification of an argument first used by J. L. Kelley (see, for example, [6; p. 39].) We give a sketch of that argument.

If $x$ and $y$ are elements of $f(A)$, then there exists a closed subset $F$ of $A$ which is minimal with respect to $\{x, y\} \subset f(F)$ and $f(a)=f(b)$ whenever $a$ and $b$ are the endpoints of a complementary interval of $A-F$. It follows from this minimality that $f(F)$ is connected and that $x$ and $y$ are the only non-cutpoints of $f(F)$. Therefore $f(F)$ is an arc, and so $f(A)$ is arcwise connected.

For the remainder of this paper $X$ is an arcwise connected Hausdorff space which contains no circle and $e \in X$. In particular, if $x$ and $y$ are distinct elements of $X$ then the arc $[x, y]$ is unique. Consequently the relation $x \leqq y$ if and only if $x \in[e, y]$ is a partial order. As usual, if $x \leqq y$ and $x \neq y$ we write $x<y$.

Of course each arc in $X$ has a natural order which does not necessarily agree with the partial order $\leqq$. If $a$ and $b$ are elements of $X$ and if $p$ precedes $q$ in the natural order on $[a, b]$, we write $[a$, $p, q, b]$.

LEMmA 2. If $a, b$ and $c$ are elements of $X$ such that $a<b$ and $a \not \leq c$, then $a \in[b, c]$.

Proof. If $b \leqq c$ then by transitivity the hypothesis that $a \geqq c$ is contradicted. Therefore, by the uniqueness of arcs there exists $d \neq$ $b$ such that $[e, b] \cap[e, c]=[e, d]$. Moreover,

$$
a \in[e, b]-[e, d] \subset[d, b] \subset[d, b] \cup[d, c]=[b, c] .
$$

Lemma 3. Let $f: X \rightarrow X$ be continuous and suppose $x$ and $t$ are elements of $X$ such that $x<t<f(x), t<f(t)$ and $f(x) \$ f(t)$. Then there exists $y \in(x, t]$ such that $f(y) \in[f(x), f(t)]$ and $f(y) \leqq f(x)$.

Proof. By the uniqueness of arcs there exists $z \in X$ such that $[z, f(x)]=[e, f(x)] \cap[f(t), f(x)] \subset[f(t), f(x)]$, and therefore by Lemma $1,[z, f(x)] \subset f([x, t])$. Because $f(x) \leqq f(t)$ and $z \leqq f(t)$ it follows that $z \neq f(x)$. Consequently there exists $y \in(x, t]$ such that $z=f(y)$.

Lemma 4. If $f: X \rightarrow X$ is continuous and if $p$ and $q$ are elements of $X$ such that $[f(p), p, q, f(q)]$, then there exists $x \in[p, q]$ such that 
$x=f(x)$.

Proof. By a straightforward maximality argument there exists $[x, y] \subset[p, q]$ which is minimal relative to $[f(x), x, y, f(y)]$. If $f(x) \neq$ $x$ then $x=f\left(x_{1}\right)$ where $x_{1} \in(x, y]$ so that $\left[x_{1}, y\right]$ contradicts the minimality of $[x, y]$. Therefore $f(x)=x$.

A subset $C$ of $X$ is called a chain if it is simply ordered with respect to the partial order $\leqq$.

Lemma 5. If $x \in X$ such that $x \geqq f(x)$ and if there exists $t_{1} \in X$ such that $t_{1} \leqq f\left(t_{1}\right) \leqq x$, then $f$ has a fixed point.

Proof. Let $T$ be a subset of $X$ which is maximal with respect to $T \cup f(T) \subset[e, x]$ and $t \leqq f(t)$ for all $t \in T$. Since $T \subset[e, x]$, there is a least upper bound $t_{0}$ of $T$. We will show that $t_{0}=f\left(t_{0}\right)$.

Suppose first that $t_{0} \not \equiv f\left(t_{0}\right)$ and $f\left(t_{0}\right) \not t_{0}$. Then there exist disjoint open sets $U$ and $V$ such that $t_{0} \in V, f(V) \subset U$ and $U \cap\left[e, t_{0}\right]=$ $\square=V \cap\left[e, f\left(t_{0}\right)\right]$. If $t \in T$ is chosen so that $\left[t, t_{0}\right] \subset V$, then $[f(t)$, $\left.f\left(t_{0}\right)\right] \subset f\left(\left[t, t_{0}\right]\right) \subset U$ since, by Lemma $1, f\left(\left[t, t_{0}\right]\right)$ is arcwise connected. Since $t<f(t)$ and $t \not \equiv f\left(t_{0}\right)$, it follows from Lemma 2 that $t \in[f(t)$, $\left.f\left(t_{0}\right)\right] \subset U$, and this contradicts our assumption that $U$ and $V$ are disjoint. Therefore, either $f\left(t_{0}\right) \leqq t_{0}$ or $t_{0} \leqq f\left(t_{0}\right)$.

If $f\left(t_{0}\right)<t_{0}$ then there exist disjoint open sets 0 and $W$ such that $t_{0} \in 0$ and $f(0) \subset W$. If $y \in T$ is chosen so that $\left[y, t_{0}\right] \subset 0$, then $[f(y)$, $\left.f\left(t_{0}\right)\right] \subset W$ and, since $f\left(t_{0}\right)<y \leqq f(y)$, it follows that $y \in W$. Again this is a contradiction and therefore $t_{0} \leqq f\left(t_{0}\right)$.

If $t_{0}<f\left(t_{0}\right)$ then there are disjoint open sets $U^{\prime}$ and $V^{\prime}$ such that $t_{0} \in V^{\prime}, f\left(V^{\prime}\right) \subset U^{\prime}$ and $U^{\prime} \cap\left[e, t_{0}\right]=\square$. If $s \in\left[t_{0}, x\right]$ is chosen so that $\left[t_{0}, s\right] \subset V^{\prime}$, then $s<f\left(t_{0}\right)$ and hence $\left[f\left(t_{0}\right), f(s)\right] \subset U^{\prime}$. By Lemma 3 there exists $z \in\left(t_{0}, s\right]$ such that $f(z) \in\left[f\left(t_{0}\right), f(s)\right]$ and $f(z) \leqq f\left(t_{0}\right)$. Since $z<f(z) \leqq f\left(t_{0}\right) \leqq x$, the maximality of the set $T$ is contradicted. Therefore $t_{0}=f\left(t_{0}\right)$.

Proof of the theorem. Let $\mathscr{S}$ denote the family of all subsets $S$ of $X$ such that $S \cup f(S)$ is a chain and $t \leqq f(t)$ for each $t \in S$. Clearly $\{e\} \in \mathscr{S}$, so by Zorn's Lemma $\mathscr{S}$ has a maximal member $S_{0}$.

Suppose $S_{0} \cup f\left(S_{0}\right) \subset[e, x]$ for some $x \in X$. If $x \not f(x)$ then $f$ must have a fixed point by Lemma 5 . If $x \leqq f(x)$ for each $x$ such that $S_{0} \cup f\left(S_{0}\right) \subset[e, x]$ then by maximality both $x$ and $f(x)$ are members of $S_{0}$ and hence $x=f(x)$.

Therefore we may assume that $S_{0} \cup f\left(S_{0}\right)$ is cofinal in some ray $R$. It follows readily that $S_{0}$ is cofinal in $R$. We will show that if 
$f\left(K_{R}\right)-K_{R} \neq \square$ then $f$ has a fixed point. Choose $y \in K_{R}$ such that $f(y) \in X-K_{R}$; then there is a generalized sequence $x_{n}$ (i.e., a function whose domain is some ordinal number) in $R$ such that $x_{n}<x_{n+1}$ and $x_{n} \rightarrow y$. Since $S_{0}$ is cofinal in $R$, the sequence $x_{n}$ can be so chosen that there exists $y_{n} \in S_{0} \cap\left[x_{n}, x_{n+1}\right]$, for each $n$.

If there exists $n_{1}$ such that $x_{n_{1}} \notin\left[e, f\left(x_{n_{1}}\right)\right]$ then $\left[f\left(y_{n_{1}}\right), y_{n_{1}}, x_{n_{1}}\right.$, $f\left(x_{n_{1}}\right)$, so that by Lemma $4, f$ has a fixed point. Consequently we may assume $x_{n} \leqq f\left(x_{n}\right)$ for each $n$. Moreover, since $f(y) \notin K_{R}$ we may assume $f\left(x_{n}\right) \notin R$, for each $n$.

If there exists $n_{2}$ such that $f\left(x_{n_{2}}\right) \leqq f\left(f\left(x_{n_{2}}\right)\right)$ then we may find $m$ such that $y_{m} \notin\left[e, f\left(f\left(x_{n_{2}}\right)\right)\right]$ and therefore $\left[f\left(y_{m}\right), y_{m}, f\left(x_{n_{2}}\right), f\left(f\left(x_{n_{2}}\right)\right)\right]$. Again, $f$ has a fixed point by Lemma 4. Hence we may assume that $x_{n}<f\left(x_{n}\right) \not f\left(f\left(x_{n}\right)\right)$. But then the hypotheses of Lemma 5 are satisfied.

\section{REFERENCES}

1. R. H. Bing, The elusive fixed point property, Amer. Math. Monthly, 76 (1969), 119-132.

2. J. K. Harris, Order Structures for Certain Acyclic Topological Spaces, University of Oregon thesis, 1962.

3. S. Mardeśič, On the Hahn-Mazurkiewicz theorem in non-metric spaces, Proc. Amer. Math. Soc., 11 (1960), 929-937.

4. T. Van der Walt, Fixed and Almost Fixed Points, Mathematical Centre Tracts, Amsterdam, 1963.

5. L. E. Ward, Jr., A fixed point theorem for chained spaces, Pacific J. Math., 9 (1959), 1273-1278,

6. G. T. Whyburn, Analytic Topology, Amer. Math. Soc. Coll. Publ., Vol. 28, New York, 1942.

7. G. S. Young, Jr., Fixed point theorems for arcwise connected continua, Proc. Amer. Math. Soc., 11 (1960), 880-884.

Received June 7, 1971 and in revised form July 29, 1971.

UNIVERSITY OF WYOMING

AND

UNIVERSITY OF OREGON 


\section{PACIFIC JOURNAL OF MATHEMATICS}

\section{EDITORS}

\author{
H. SAMELSON \\ Stanford University \\ Stanford, California 94305 \\ C. R. HOBBY \\ University of Washington \\ Seattle, Washington 98105
}

\author{
J. DugundJI \\ Department of Mathematics \\ University of Southern California \\ Los Angeles, California 90007
}

\author{
RICHARD ARENS \\ University of California \\ Los Angeles, California 90024
}

\section{ASSOCIATE EDITORS}
E. F. BECKENBACH
B. H. NeumanN
F. WOLF
K. YoSHIDA

\section{SUPPORTING INSTITUTIONS}

\author{
UNIVERSITY OF BRITISH COLUMBIA \\ CALIFORNIA INSTITUTE OF TECHNOLOGY \\ UNIVERSITY OF CALIFORNIA \\ MONTANA STATE UNIVERSITY \\ UNIVERSITY OF NEVADA \\ NEW MEXICO STATE UNIVERSITY \\ OREGON STATE UNIVERSITY \\ UNIVERSITY OF OREGON \\ OSAKA UNIVERSITY
}

\author{
UNIVERSITY OF SOUTHERN CALIFORNIA \\ STANFORD UNIVERSITY \\ UNIVERSITY OF TOKYO \\ UNIVERSITY OF UTAH \\ WASHINGTON STATE UNIVERSITY \\ UNIVERSITY OF WASHINGTON \\ $* * * *$
$*$
AMERICAN MATHEMATICAL SOCIETY
NAVAL WEAPONS CENTER
}

The Supporting Institutions listed above contribute to the cost of publication of this Journal, but they are not owners or publishers and have no responsibility for its content or policies.

Mathematical papers intended for publication in the Pacific Journal of Mathematics should be in typed form or offset-reproduced, (not dittoed), double spaced with large margins. Underline Greek letters in red, German in green, and script in blue. The first paragraph or two must be capable of being used separately as a synopsis of the entire paper. The editorial "we" must not be used in the synopsis, and items of the bibliography should not be cited there unless absolutely necessary, in which case they must be identified by author and Journal, rather than by item number. Manuscripts, in duplicate if possible, may be sent to any one of the four editors. Please classify according to the scheme of Math. Rev. Index to Vol. 39. All other communications to the editors should be addressed to the managing editor, Richard Arens, University of California, Los Angeles, California, 90024.

50 reprints are provided free for each article; additional copies may be obtained at cost in multiples of 50 .

The Pacific Journal of Mathematics is published monthly. Effective with Volume 16 the price per volume (3 numbers) is $\$ 8.00$; single issues, $\$ 3.00$. Special price for current issues to individual faculty members of supporting institutions and to individual members of the American Mathematical Society: $\$ 4.00$ per volume; single issues $\$ 1.50$. Back numbers are available.

Subscriptions, orders for back numbers, and changes of address should be sent to Pacific Journal of Mathematics, 103 Highland Boulevard, Berkeley, California, 94708.

PUBLISHED BY PACIFIC JOURNAL OF MATHEMATICS, A NON-PROFIT CORPORATION

Printed at Kokusai Bunken Insatsusha (International Academic Printing Co., Ltd.), 270, 3-chome Totsuka-cho, Shinjuku-ku, Tokyo 160, Japan. 


\section{Pacific Journal of Mathematics}

\section{Vol. 43, No. 2 \\ April, 1972}

Arne P. Baartz and Gary Glenn Miller, Souslin's conjecture as a problem on the real line....................................... 277

Joseph Barback, On solutions in the regressive isols ............... 283

Barry H. Dayton, Homotopy and algebraic K-theory ................ 297

William Richard Derrick, Weighted convergence in length ............ 307

M. V. Deshpande and N. E. Joshi, Collectively compact and semi-compact sets of linear operators in topological vector spaces ............. 317

Samuel Ebenstein, Some $H^{p}$ spaces which are uncomplemented in $L^{p} \ldots . .327$

David Fremlin, On the completion of locally solid vector lattices ......... 341

Herbert Paul Halpern, Essential central spectrum and range for elements of

a von Neumann algebra............................... 349

G. D. Johnson, Superadditivity intervals and Boas' test ............. 381

Norman Lloyd Johnson, Derivation in infinite planes . . . . . . . . . . . 387

V. M. Klassen, The disappearing closed set property .............. 403

B. Kuttner and B. N. Sahney, On the absolute matrix summability of Fourier series ........................................... 407

George Maxwell, Algebras of normal matrices................... 421

Kelly Denis McKennon, Multipliers of type $(p, p) \ldots \ldots \ldots \ldots \ldots \ldots . . \ldots 29$

James Miller, Sequences of quasi-subordinate functions ............. 437

Leonhard Miller, The Hasse-Witt-matrix of special projective varieties ..... 443

Michael Cannon Mooney, A theorem on bounded analytic functions ...... 457

M. Ann Piech, Differential equations on abstract Wiener space .......... 465

Robert Piziak, Sesquilinear forms in infinite dimensions ............. 475

Muril Lynn Robertson, The equation $y^{\prime}(t)=F(t, y(g(t))) \ldots \ldots \ldots \ldots .483$

Leland Edward Rogers, Continua in which only semi-aposyndetic

subcontinua separate ............................... 493

Linda Preiss Rothschild, Bi-invariant pseudo-local operators on Lie

groups ...................................... 503

Raymond Earl Smithson and L. E. Ward, The fixed point property for

arcwise connected spaces: a correction ...................... 511

Linda Ruth Sons, Zeros of sums of series with Hadamard gaps .......... 515

Arne Stray, Interpolation sets for uniform algebras............... 525

Alessandro Figà-Talamanca and John Frederick Price, Applications of random Fourier series over compact groups to Fourier multipliers .. 